\title{
FACTORS ASSOCIATED WITH HEMOGLOBIN LEVEL IN PREGNANT WOMEN
}

\section{Indah Permatasari Sinawangwulan'), Yulia Lanti Retno Dewi²), CSP. Wekadigunawan3)}

\author{
${ }^{1)}$ Masters Program in Public Health, Universitas Sebelas Maret \\ ${ }^{2)}$ Department of Nutrition, Faculty of Medicine, Universitas Sebelas Maret \\ 3)Faculty of Medicine, Universitas Sebelas Maret
}

\begin{abstract}
Background: Anemia in pregnancy is defined as a hemoglobin concentration of less than $110 \mathrm{~g} / \mathrm{L}$ (less than $11 \mathrm{~g} / \mathrm{dL}$ ) in venous blood. It affects more than 56 million women globally, two-thirds of them being from Asia. Anemia increases perinatal risks for mothers and neonates; and increases overall infant mortality. The odds for fetal growth restriction and low birth weight are tripled. The odds for preterm delivery are more than doubled. Even a moderate hemorrhage in an anemic pregnant woman can be fatal. Anemia is the major contributory or sole cause in $20-40 \%$ of maternal deaths. Many women go through the entire pregnancy without attaining the minimum required intake of iron. The purpose of this study was to investigate factors associated with hemoglobin level in pregnant women.

Subjects and Method: This was a cross-sectional study carried out Karanganyar, Central Java, from February to March 2018. A sample of 200 pregnant women was selected for this study by fixed disease sampling, comprising 50 women with anemia and 150 women without anemia. The dependent variable was hemoglobin level. The independent variables were iron tablet consumption, nutrition intake, dietary culture, and family size. Data on hemoglobin level were taken from medical record. The other variables were measured by questionnaire. The data were analyzed by a multiple linear regression.

Results: Hemoglobin level increased with adequate iron tablet consumption ( $b=$ $0.38 ; 95 \% \mathrm{CI}=10.79$ to $11.37 ; \mathrm{p}<0.001)$ and better nutrition intake $(\mathrm{b}=0.46 ; 95 \%$ $\mathrm{CI}=0.17$ to $0.75 ; \mathrm{p}=0.002)$. Hemoglobin level decreased with inhibitory dietary culture $(\mathrm{b}=-0.28 ; 95 \% \mathrm{CI}=-0.55$ to $<0.01 ; \mathrm{p}=0.050)$ and larger family size $(\mathrm{b}=-$ $0.30 ; 95 \% \mathrm{CI}=-0.63$ to $0.03 ; \mathrm{p}=0.070)$.

Conclusion: Adequate iron tablet consumption and better nutrition intake increase hemoglobin level. Inhibitory dietary culture and larger family size decrease hemoglobin level.
\end{abstract}

Keywords: hemoglobin level, anemia, iron tablet consumption, nutrition intake, family size, pregnant women

Correspondence:

Indah Permatasari Sinawangwulan. Masters Program in Public Health, Universitas Sebelas Maret. Jl. Ir. Sutami No. 36 A, 57126, Surakarta, Central Java. Email: siindahnawang@gmail.com. Mobile: 085655261261.

The 4th International Conference on Public Health Best Western Premier Hotel, Solo, Indonesia, August 29-30, 2018 | 203 https://doi.org/10.26911/theicph.2018.03.34 